\title{
РЕЦЕНЗИИ
}

\section{Doomed to Socialism ${ }^{1}$}

\section{V.Sinyutin}

Saint Petersburg State University,

7-9, Universitetskaya nab., Saint Petersburg, 199034, Russian Federation

Sociological Institute of the Russian Academy of Sciences,

25/14, 7-ya Krasnoarmeyskaya str., Saint Petersburg, 190005, Russian Federation

For citation: Sinyutin M.V. Doomed to Socialism. Vestnik of Saint Petersburg University. Sociology, 2018, vol. 11, issue 2, pp. 258-261. https://doi.org/10.21638/11701/spbu12.2018.209

Well known Egyptian-born thinker Samir Amin belongs to the sociological tradition of Worldsystems analysis. Educated in Egypt (Port-Said) and France (Paris) he had become known since the 1970s as one of the creators, together with A. Frank, I. Wallerstein, G. Arrighi, of the new approach that combines Marxism with geopolitics. It was a historical chain that links theories of imperialism with theories of globalization. The core of his thought is the capitalist inequality at the level of nations and states. From the very beginning in his thesis at 1957 Samir Amin had written dozens of books that become popular and disputable. His recent book at the age of $85^{\text {th }}$ has been focused on Russia and its role in the modern world system. This demonstrates his vision of the importance of Russia in current global order.

The monograph is a fruit of Samir Amin's intensive thinking during the years after demise of the Soviet Union, written in form of the self-sufficient but correlated essays. He claims that "by using a scientifically accurate analysis of history" the essays "contribute to shaping an image of Russia that is quite different from the one that is disseminated in the propaganda of the Western countries" (p. 6). This seems to be attractive for those involved in the studies on Russian issues. As a Maitre of contemporary social thought Samir Amin uses the style of writing with sparse quotations and references. He prefers to show his readers the transparent path of his thinking.

In his starting essay the author follows historical and geographical approaches to emphasize the issue of Russian role and place within the global system. In essence he studies historical social system in terms of capitalism but considering dependency of the concrete countries on the development of the whole. He finds Russian way to the epoch of capitalism in conjuncture to the main blocks of the earlier world system, which are China, India, Middle East, and Europe. Rise of capitalism moved Europe at the top to get subordinated to it any other world blocks, but Russian path had lacked economic

${ }^{1}$ Book review: Amin S. Russia and the Long Transition from Capitalism to Socialism. New York, Monthly Review Press, 2016. 144 p.

() Санкт-Петербургский государственный университет, 2018 
exploitation of the countries politically included within the borders of Empire. Russia escaped European-style colonialism but didn't avoid European conflicts. Besides unlike United States Russia had experienced feudalism for some centuries. This capitalist under-development pays according to Samir Amin the decisive role in 1917 Russian revolution and shift to socialist government that was the similar case for the China that escaped full colonization and "peripherization". The later failure of the Soviet system he speculates as "a case of freeing oneself from its superficial kind of exercise and looking at the future from the viewpoint of an analysis of the present and its new features and comparing this with the past" (p. 19). This idea means that according to the logic of development of entire capitalist globe, Russia will suffer from the pressure of more developed capitalist centers searching its way up only on anti-capitalist direction.

The second essay compares Czarist Empire to Colonial Empires. The author challenges the current media discourse on the mode and tools of formation of Russian and then Soviet state. "The czars, precisely because their systems was not yet a capitalist one, conquered territories without dispossessing the inhabitants" (p.28). In later times, according to Samir Amin, Soviet government had practiced systematic transfers of capital from Russian regions to ethnically non-Russian territories, inventing an authentic development assistance strikingly contrasted to the western-style false development help. Therefore, nor the people neither the political leaders of national republics of the USSR, as he stresses, intended to separate from Russia. He shows that recent attack on Russia is continues the old policy lead by financial capital of the West to destroy the governmental structures that can resist it globally. Financial capital uses the force of only triad governments (US, EU, Japan) to manage globally, producing and abusing new comprador bourgeoisie at the rest of the world. Samir Amin concludes that "the development of globalized capitalism at all stages of its history, today within the framework of the emergence of a globalized production system just as much as at earlier stages, can only produce, reproduce, and deepen the center/periphery contrast" (p. 39).

Third essay summarizes Amin's experience of criticizing the Soviet System during 1960-1990s. Sympathizing to Chinese way of building socialism, he ceased to consider Soviet society as socialist due to depolitization of working masses and monopolization of power by bureaucracy headed by political bureaucracy of the Party. Despite understanding of soviet ruling class as bourgeois, Samir Amin had refused to describe the Soviet society as being capitalist because of different logic of capital accumulation under the state command of property and a significant bunch of social rights won by workers. He had characterized this system in terms of "Soviet mode of production" produced by crude but inevitable 1917 Revolution. Samir Amin confesses his fault to believe the stability of Soviet system. And this also appears to be instability of the worldwide long historical transition from Capitalism to Socialism. On the other hand, he blames the discourse on "totalitarianism" to lack the coherence and being nonrealistic. Bipolar system of the XX century, according to the author, was always asymmetrical since the USSR can compete just in military terms but not economically. Certain political support of the Soviet Union was achieved by liberation movement and national radicalism of the Third Word. Soviets never dictate to the developing countries like the West did but fails to associate with them in transition beyond capitalism. Samir Amin concludes that "rebuilding of unified world system, as system beyond capitalist polarization, requires... a breakup of the system of capitalist centralization of surplus" (p.67).

The author in the short essay groundlessly named "Lenin and Stalin: facing the challenge of the century" has focused on reasoning and decision-making processes of communist leaders in Russia and China. In fact he examines experience of rulers of major anti-capitalist revolutionary governments at the XX century. Their core intention was to liberate themselves "from the straitjacket that imperialism always wants to impose on all peripheries of the world system that it dominates" (p. 70). Samir Amin consider this caused the clear understanding by leaders of the need to build competitive armed forces, implying rapid industrialization although threatening to break the vital and fragile alliance between workers and peasants. From the other point, foreign political strategy of Soviet Union looks to be multiply oriented (on West, China, and the South) to pave the road within the capitalist world system. Chinese method of solving agrarian question has been evaluated by Samir Amin as more appropriate 
model for the South. It had restricted chances of implementing Soviet economic practices at this part of the globe. Finally, he compares French, Russian, and Chinese cases to search the processes of restoration after "Thermidor". He thinks that in Russia it happened with Gorbachev and Yeltsin rule, but still remains very fragile.

In the next and highly important essay Samir Amin portrays the challenges that post-Soviet Russia has faced. In advance, he poses five basic features of the late Soviet Society: corporatism, autocratic power, social stabilization, economic delinking from the global capitalist system, and integration into the global capitalist system as a superpower. Corporatism includes the lost of unifying political consciousness by working class being confronted within the competition of enterprises, the acceptance of "rationally planned" macro-economic management, the regionalism as a principle of economic redistribution in favor of national republics. Autocratic power means the structure of the system comprised a pyramid of powers ranging from the management of local interests to unionist and republican interests. Social stabilization of the Soviet society had successfully occurred despite the waves of violent social conflicts related with revolution, industrialization, and the Second World War although producing power system that had been braking the further movement to Socialism. Economic delinking was very ambivalent due to the semi-independence of the country from the capitalist centers, when Soviet Union occupied peripheral positions as an exporter of raw materials. Soviet military strength helps survival of socialist trends globally and imposing the multipolar world order. Notwithstanding increase the capitalist tendencies in recent three decades "new forms of capitalism in Russia have increased rather than reduced the characteristics of a Soviet system that has an extreme stage of decline" (p.89). Minor peripheral role that Russia plays in contemporary capitalist system Samir Amin attribute to the Russian new ruling bourgeois class inherited the soviet elite and prospering on the rent from oil, "cannibalization of industries", and commissions from opening Russian markets up to imports. He also stresses the strategy of imperialist triad (US, UK, and Japan) to completely "Latin-Americanize" the former Soviet Union territory. Autocratic Russian power serves the interests of oligarchy and of globalized foreign capital. However the author finds the trends in power, especially at the presidential level, to separate the governmental policy and interests from those of local and global capitalists. He speculates the future prospects of Russian international role in its competition with West to be less and less active. Low political activity of Russian masses has manifested in decline of political parties and trade unions which are not able to serve the peoples basic social interests. To prevent the use of regionalism by autocratic clans Russian, according to Samir Amin, president Putin can be credited with territorial reform of state powers. On the other hand, he asserts that new bourgeois class in Russia lost any valuable ideological justification to the people, so that Russian government turns to patriotism as a last hope. Samir Amin claims: "There is no doubt that serious alternative views derived from a criticism of Sovietism from the left, who aim to forge ahead with socialist reconstruction, would find favorable terrain in Russia. However, there is no choice but to accept that up till now these visions have not moved out of left intellectual circles and have no hold on the people" (p. 100). The author's proposals of alternative Russian domestic policy are mixed economy with private property and state control, institutionalization of worker/enterprise/state collective bargaining, and representative democracy. But these also means re-nationalization of large enterprises, invention of new joint management practices, reinforcement of public social services, education and science, substitution of the 1993 constitution, popular intervention of participative democracy reconstruction of transnational association of the former Soviet republics, re-establishment of Russian armed forces, developing arrangements with European states, and liberation of foreign policy from US influence. With the evident sympathy to socialism Samir Amin regrets that European left does not participate in socialist reconstruction of Russia but only contributes to the continuation of its confusion. Deliberately they just participate in the Atlanticist plan of destroying Russia as a state. But his hope lies at the side of Eurasian unity, based of Russia, China, and India as the only chance of the Third World to get subordinated to the West imperialism for the ages.

The topical essay Samir Amin has dedicated to the issue of Ukrainian crisis. He finds that attempts of Russian government to resist western strategy of its peripherization returned them to the tested tool 
of fascism. "Fascism is a particular political response to the challenges with which the management of capitalist society may be confronted in specific circumstances" (p. 108). Often specific cases are based on support of corporate capitalist interests by illegitimate political force and rejection of democratic processes. After the brief historical survey of fascist regimes, the author shows the convergence of interests between global Western imperialism and local Ukrainian fascism. And he stresses the international factor as decisive for the current conflict in Ukraine. "The Ukrainian conflict is thus part of a larger context in which the strategy deployed by Washington and its subaltern European allies is coming up against the - albeit confused - aspirations of the people, nations, and even states of the contemporary periphery: Russia and the other countries of the former Soviet Union as well as those of Asia, Africa, and Latin America" (p. 125). Eventually Samir Amin highlights that the main obstacle for Russia to untangle the knot of Ukrainian crisis is the comprador fraction of the Russian ruling class.

In the last essay of the book the author explains the history of Russia as acquiring its meaning only when placed within the global history. But he warned about the common mistakes of "apriorism" (treating the West as democracy and other worlds as despotism), "cyclism" (application of the tendencies in earlier historical societies to the current social forms), and "amateurism" (lack of qualified scholar experience in the field), that are widespread around discussions of Russian history. Guided by Marxian historical Materialism and expertise of political activism Samir Amin outlines the vital contradiction of current Russian historical stage: political leader of the state (Putin) remains the partisan of market capitalist system chaired by capitalist monopolies while this system brings the management that gives no chance against the permanent aggression of imperialist West.

Distinctive peculiarity of the book consists of the idea that Russian historical route at a current stage gives no choice to follow Socialist goals. Despite the debatableness and the lack of validity of some essential provisions in the book, his central argument says that the logic of capitalist World system constantly produces the efforts to build the new non-capitalist social order and Russia being inevitably excluded from the imperialist elite doomed to join once started great upheaval that produced long movement to overcome capitalism. This volume by Samir Amin can be valuable for those interested in World system sociological theory and modern geopolitics, as well as those who monitor recent trends in Russian political life.

Received: 20.02.2018

Accepted: 22.02 .2018

Author's information:

Mikhail V. Sinyutin — Doctor of Sociology, Professor; sinewtin@yandex.ru 